\title{
Penambahan Daging Ikan Asal Waduk Cirata Terhadap Tingkat Kesukaan Kecimpring Singkong
}

\author{
Addition of Meat Fish Origin From Cirata Reservoir to The Level \\ Consumer Preference of Cassava Chips
}

\author{
Nia Kurniawati, Junianto, Iis Rostini \\ Staff Pengajar FPIK Universitas Padjadjaran \\ Jl.Raya Bandung Sumedang KM.21 Jatinangor \\ Email: iis.rostini@unpad.ac.id
}

\begin{abstract}
Abstrak
Penelitian ini bertujuan untuk mengetahui persentase penambahan daging ikan pada kecimpring singkong yang paling disukai panelis. Ikan yang digunakan dalam penelitian adalah ikan nila, ikan bawal, dan ikan patin yang berasal dari Waduk Cirata. Penelitian terdiri dari dua tahap yaitu pembuatan daging lumat dan pembuatan kecimpring. Metode penelitian yang digunakan adalah eksperimental dengan tiga perlakuan yaitu penambahan daging ikan nila, bawal, dan patin dengan empat faktor. Kecimpring dibuat dengan berbagai konsentrasi yaitu $0 \%, 10 \%, 20 \%$ dan 30\% berdasarkan berat singkong. Parameter yang diamati meliputi karakteristik organoleptik (warna, kerenyahan, aroma dan rasa) dan uji kimia (kadar air, kadar protein, kadar lemak, dan kadar abu untuk perlakuan kontrol dan paling disukai). Hasil penelitian menunjukkan bahwa daging ikan tidak memberikan pengaruh yang nyata terhadap warna, kerenyahan, aroma, dan rasa kecimpring singkong. Penambahan $10 \%$ daging ikan patin menghasilkan kecimpring yang paling disukai dibandingkan dengan perlakuan lainnya, dengan nilai alternatif tertinggi 7,20; kadar air 11,45\%; kadar protein 5,81\%; kadar lemak 1,20\% dan kadar abu 4,82\%.
\end{abstract}

Kata kunci:Waduk cirata, penambahan daging ikan ,kecimpring,tingkat kesukaan,

\begin{abstract}
This study aimed to determine the percentage of fish meat addition on cassava kecimpring the most preferred by panelists. The fish used in the study were tilapia, pomfret, and catfish, collected from Cirata Reservoir. The study consisted of two steps, namely the minced fish preparation and kecimpring preparation. The method used was experimental with three treatments, the addition of tilapia , pomfret , and catfish meat with four factors. Kecimpring made with various concentrations of $0 \%, 10 \%, 20 \%$ and $30 \%$ by weight of cassava. The parameters observed were organoleptic characteristics (color, crispness, aroma and taste) and chemical test (moisture, protein, lipid, and ash content for the control treatment and the most preferred). The results showed that the addition of fish meat does not give a significant effect on the kecimpring cassava color, crispness, aroma, and taste. The addition $10 \%$ of fish meat on cassava kecimpringwas the most preferred compared with other, the alternative value was the highest 7.20 ; water content of $11.45 \%$; protein content of $5.81 \%$; fat content $1.20 \%$ and ash content of $4.82 \%$.
\end{abstract}

Keywords : Cirata reservoir, fish meat additiont, kecimpring, preferrence, 
Nia Kurniawati :Penambahan Daging Ikan Asal Waduk Cirata Terhadap Tingkat Kesukaan Kecimpring Singkong

\section{Pendahuluan}

Kecimpring singkong merupakan produk olahan yang berbahan dasar singkong. Produk ini dijadikan sebagai makanan "camilan" oleh sebagian besar masyarakat di Jawa Barat. Produk kecimpring singkong sebagai makanan camilan banyak disukai oleh berbagai kalangan, dari orang dewasa sampai anak-anak baik laki-laki ataupun perempuan semuanya menyukai kecimpring singkong.

Produk kecimpring singkong sebagai pangan lokal memiliki potensi untuk dikembangkan menjadi produk nasional. Peningkatan mutu kecimpring dapat dilakukan baik secara fisik dan kimia. Secara fisik melalui modifikasi bentuk kecimpring singkong. Secara kimia melalui suplementasi daging ikan sehingga kandungan protein kecimpring singkong menjadi lebih tinggi. Berdasarkan bahan baku yang digunakan,kecimpring singkong memiliki kandungan gizi yang tidak seimbang yaitu kaya akan karbohidrat tetapi miskin protein. Berkenaan dengan ketidak seimbangan mutu gizi tersebut, upaya yang dapat dilakukan adalah suplementasi dengan daging ikan.

Ikan nila, bawal dan patin dapat ditambahkan ke dalam produk olahan karena dagingnya berwarna putih, rasa dan aromanya netral, sertadagingnya tebal. Ikan nila, bawal dan patin memiliki kandungan protein yang tinggi. Kandungan protein ikan nila adalah $12,52 \%$ (Suyanto 1994). Kandungan protein ikan bawal adalah 12,86\% (Sukmaningrum et al. 2009) dan kandungan protein ikan patin adalah 12,94\% (Suryaningrum et al. 2010). Dengan demikian ketiga ikan tersebut dapat digunakan untuk meningkatkan kandungan protein jika ditambahkan pada produk olahan. Ikan nila, bawal, dan patin mudah diperoleh karena sudah banyak dibudidayakan salah satunya di Waduk Cirata Jawa Barat.

Suplementasi daging ikan pada kecimpring singkong, selain mempengaruhi komposisi zat gizinya terutama kandungan protein, kemungkingan juga berpengaruh terhadap karakteristik organoleptik kecimpring yang dihasilkan. Karakteristik organoleptik tersebut meliputi warna, kerenyahan, aroma, dan rasa.. Komposisi dan citarasa produk kecimpring hasil suplementasi ini dapat dipengaruhi oleh konsentrasi suplementasi daging dan jenis ikannya, sehingga perlu diteliti tingkat kesukaan kecimpring singkong hasil suplementasi. Penelitian ini bertujuan untuk mengetahui persentase penambahan daging ikan pada kecimpring singkong yang paling disukai panelis.

\section{Bahan dan Metode}

\section{Bahan dan Alat}

Bahan baku utama yang digunakan untuk pembuatan kecimpring adalah singkong, ikan nila (Oreochromis niloticus), ikan bawal (Colossoma macropomum), dan patin (Pangasius hypopthalmus) yang diperoleh dari Waduk Cirata, dan bahan tambahan lain yang digunakan yaitu garam, gula putih,bawang putih, dan bawang merah. Alat yang digunakan meliputi baskom, coolbox, talenan, pisau, meat grinder, kompor, pengukus, rak penjemuran, dan peralatan untuk uji kimia (timbangan analitik, soxlet, kjehdal, oven, desikator, tanur, buret).

\section{Metode Penelitian}

Metode penelitian yang digunakan adalah eksperimental dengan tiga perlakuan yaitu penambahan daging ikan nila, bawal, dan patin dengan empat faktor. Kecimpring dibuat dengan berbagai konsentrasi yaitu $0 \%, 10 \%$, $20 \%$ dan $30 \%$ berdasarkan berat singkong. Tahap penelitian terdiri dari dua tahap, yaitu pembuatan daging lumat dan pembuatan kecimpring. Tahapan pembuatan daging lumat dan pembuatan kecimpring disajikan pada Gambar 1 dan 2. 


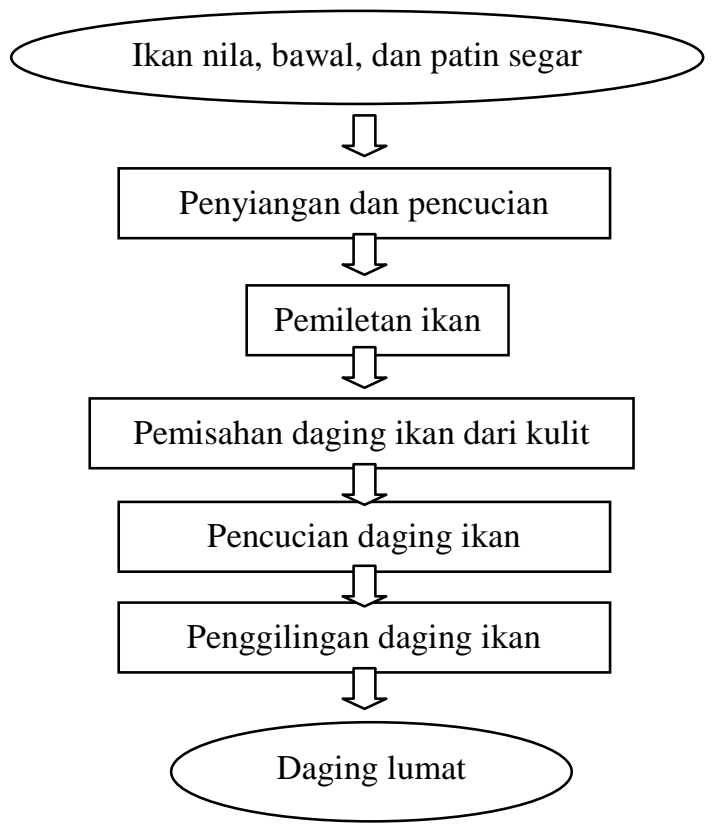

Gambar 1. Pembuatan daging lumat Figure 1. Production of Pulp Meat

Daging lumat yang dihasilkan selanjutnya ditambahkan pada adonan kecimpring berdasarkan perlakuan yang telah ditentukan.
Bumbu yang digunakan dalam pembuatan kecimpring adalah garam $2 \%$, gula putih $2 \%$, bawang putih $2 \%$, dan bawang merah $2 \%$.

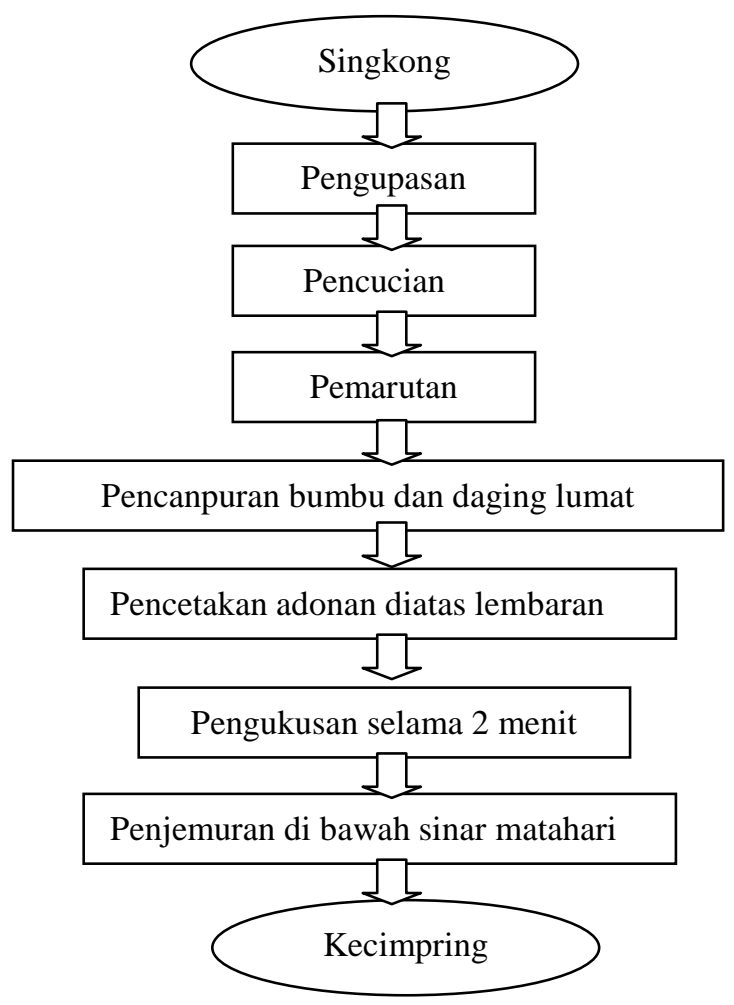

Gambar 2. Pembuatan kecimpring dengan suplementasi daging ikan Figure 2. Production of cassava chip with suplementation of fish meat 
Nia Kurniawati :Penambahan Daging Ikan Asal Waduk Cirata Terhadap Tingkat Kesukaan Kecimpring Singkong

\section{Pengamatan Mutu}

\section{Penilaian Organoleptik}

Pengujian organoleptik dilakukan terhadap kecimpring yang sudah digoreng dengan menggunakan uji hedonik (uji kesukaan terhadap warna, kerenyahan, aroma, dan rasa kecimpring), untuk mengetahui tingkat penerimaan konsumen terhadap kecimpring yang dihasilkan dalam penelitian. Penelitian dilaksanakan dengan menggunakan skala hedonik. Nilai kesukaan konsumen berkisar 1 9yaitu: paling rendah 1 (sangat tidak suka) 3 (tidak suka), 5 (netral/biasa), 7 (suka) dan nilai tertinggi 9 (sangat suka) dengan menggunakan 20 orang panelis semi terlatih.Batas penolakan untuk produk lebih kecil atau sama dengan 3 artinya produk tidak diterima panelis.

\section{Analisis Proksimat}

Analisis proksimat dilakukan terhadap kecimpring yang telah kering dan masih mentah. Analisis proksimat meliputi analisis kadar air, kadar protein, kadar lemak, dan kadar abu untuk perlakuan kontrol dan yang paling disukai.

\section{Hasil dan Diskusi}

\section{Organoleptik}

Hasil pengujian organoleptik dengan uji hedonik disajikan pada Gambar 3 dan hasil uji Bayes disajikan pada Gambar 4. Hasil uji organoleptik dengan metode uji kesukaan terhadap warna diperoleh nilai rata-rata antara 4,9 dan 7,5 sedangkan nilai median tertinggi 7 dan terkecil 5. Hal ini berarti kecimpring yang dihasilkan berdasarkan warna berkisar antara netral hingga disukai. Berdasarkan hasil uji Kruskal-Wallis dan Uji Median, penambahan daging ikan tidak memberikan pengaruh yang nyata terhadap warna kecimpring. Pada setiap perlakuan, menghasilkan karakteristik warna yang berbeda-beda, semakin banyak persentase daging ikan yang ditambahkan, warna kecimpring ikan semakin coklat. Hal ini karena daging ikan mengandung protein yang tinggi. Protein(gugus amina primer) bereaksi dengan gula pereduksi dari karbohidrat akan menghasilkan warna coklat yang dikenal sebagai reaksi Maillard (Winarno 1997). Nilai rata-rata warna tertinggi pada perlakuanpenambahan daging ikan patin $10 \%$. Warna bahan pangan merupakan atribut sensori yang mempengaruhi kualitas dan penerimaan produk pangan. Warna merupakan atribut sensori yang sangat penting dan harus selalu dipertimbangkan, karena mempunyai pengaruh secara langsung terhadap kualitas suatu produk (Niamnuy 2008).

Hasil uji kesukaan terhadap kerenyahan dihasilkan nilai rata-rata antara 5,9 sampai 7,8 dan nilai median terkecil 6 sedangkan median yang tertinggi adalah 8. Hasil tersebut menunjukkan bahwa berdasarkan kerenyahan kecimpring disukai oleh panelis. Nilai rata-rata kerenyahan kecimpring tertinggi yaitu pada perlakuan penambahan daging ikan patin $10 \%$. Persentase penambahan daging ikan dalam jumlah banyak dapat menurunkan kerenyahan/mengeraskan tektur kecimpring ikan karena kandungan protein dan lemak pada daging ikan dapat menghambat proses gelatinisasi. Semakin tinggi tingkat kemekaran kerupuk, maka semakin tinggi kerenyahannya (Apriliana 2005). Implementasi protein pada formulasi snak pati singkong menunjukkan manfaat dan sesuai untuk pengaruhnya terhadap peningkatan karakteristik tekstur (Gibert dan Rakshit 2005). Berdasarkan hasil uji Kruskal-Wallis dan Uji Median, penambahan daging ikan tidak memberikan pengaruh yang nyata terhadap kerenyahan kecimpring. 


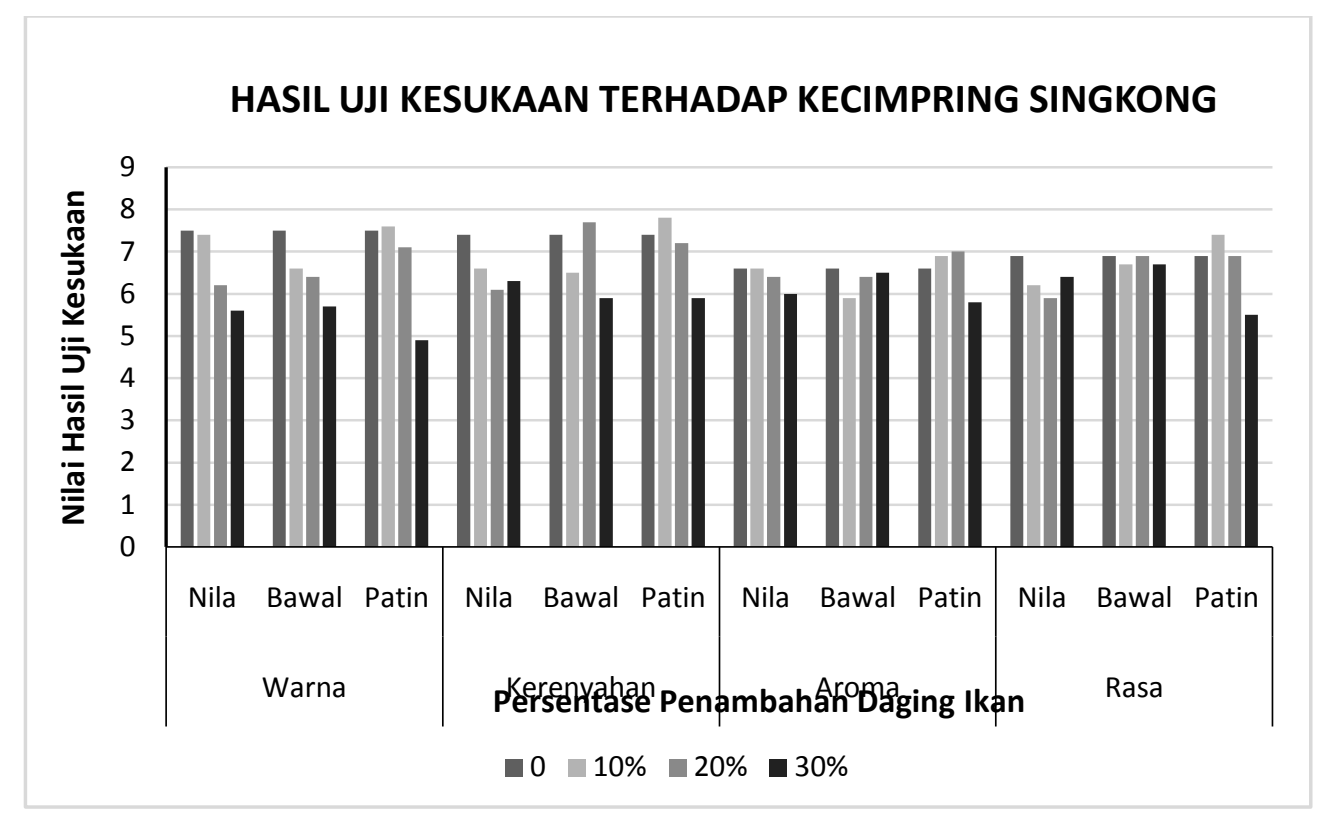

Gambar 3. Hasil keseluruhan penelitian terhadap uji kesukaan kecimpring

Figure 3. Overall Result of Study Consumer Preference Test

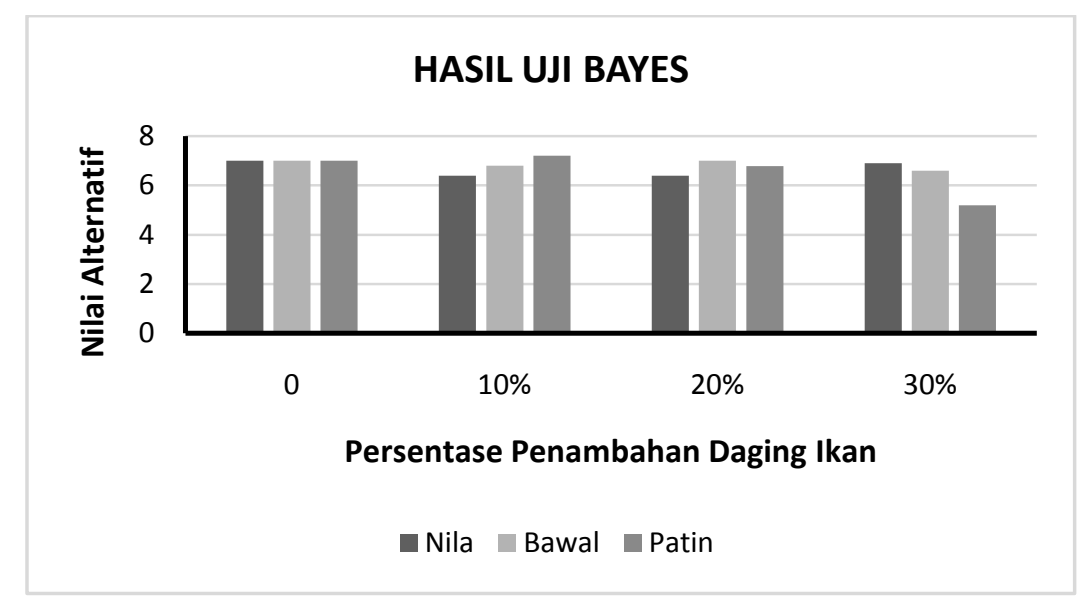

Gambar 4. Hasil Uji Bayes Kecimpring

Figure 4. Result Bayes Test oc Cassava Chip

Penerimaan suatu produk makanan ditentukan oleh faktor aroma. penilaian aroma bertujuan untuk menentukan kelezatan bahan makanan berdasarkan indera penciuman. Aroma pada produk pangan sebagian besar berasal daribumbu-bumbu yang ditambahkan pada adonan (Soekarto 1985). Nilai rata-rata aroma kecimpring berkisar antara 5,8 sampai 7. Berarti aroma kecimpring disukai oleh panelis. Aroma tambahan yang munculpada produk gorengan karena adanya minyak goreng (Aprilina 2005). Hal tersebut disebabkan karena pada produk gorengan telah terjadi penguapan sebagian komponen volatil dan terbentuknya citarasa alami akibat perubahan struktur lemak, protein dan karbohidrat (Fellow 2000). Berdasarkan hasil uji Kruskal-Wallis dan Uji Median, penambahan daging ikan tidak memberikan pengaruh yang nyata terhadap aroma kecimpring.

Rasa merupakan faktor penting yang menjadi dasar diambilnya keputusan oleh konsumen terhadap diterimanya suatu produk. Apabila sebuah produk mempunyai rasa yang tidak enak, maka produk tersebut tidak akan 
Nia Kurniawati :Penambahan Daging Ikan Asal Waduk Cirata Terhadap Tingkat Kesukaan Kecimpring Singkong

diterima oleh konsumen walaupun warna dan aromanya baik (Winarno 2008). Hasil rata-rata penilaian panelis terhadap rasa kecimpring berkisar antara 5,5 sampai 7,4 dengan nilai median terkecil 5 dan terbesar 7 . Nilai rasa paling tinggi adalah pada perlakuan penambahan daging ikan patin $10 \%$ dengan rasa yang enak dan gurih. Semakin tinggi penambahan daging ikan pada kecimpring, semakin rendah nilai rata-rata rasa, karena rasa yang dihasiolkan terlalu gurih. Berdasarkan hasil uji Kruskal-Wallis dan Uji Median, penambahan daging ikan tidak memberikan pengaruh yang nyata terhadap rasa kecimpring.

\section{Nilai Gizi Kecimpring}

Kecimpring dengan penambahan daging ikan yang dianalisis nilai gizinya adalah kecimpring dengan perlakuan kontrol dan perlakuan yang paling disukai. Berdasarkan hasil uji dengan Metode Bayes, penambahan daging ikan patin $10 \%$ menghasilkan kecimpring yang paling disukai dibandingkan dengan perlakuan lainnya, dengan nilai alternatif 7,20. Hasil analisis proksimat disajikan pada Gambar 5.

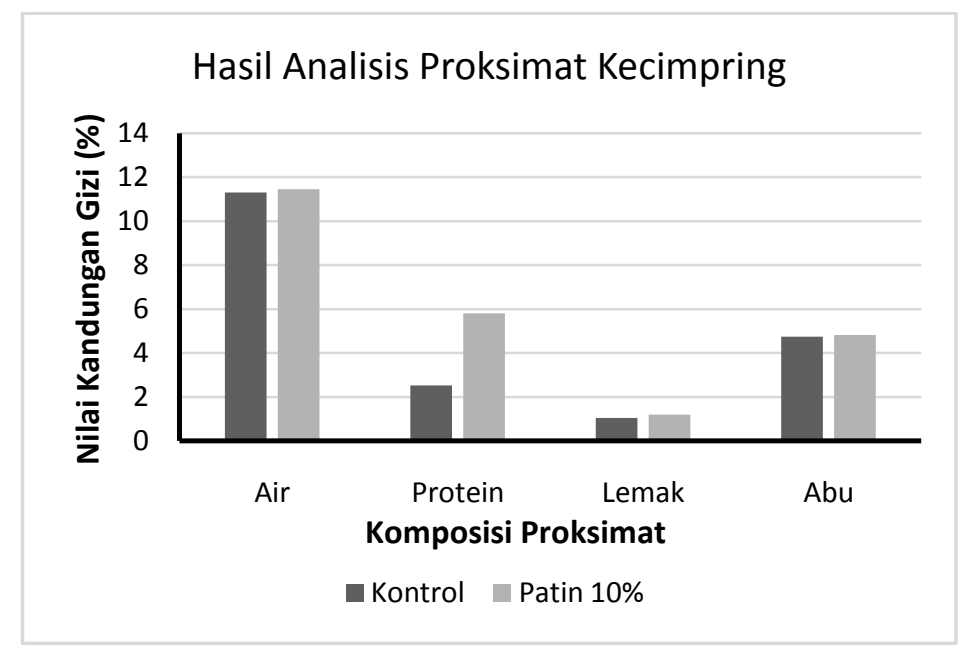

Gambar 5.Komposisi proksimat kecimpring berdasarkan perlakuan yang paling disukai Figure 5. Proximate composition of cassava chip based on the most preferred treatment

Berdasarkan Gambar 5. menunjukkan kandungan air, protein, lemak, dan abu surimi yang ditambahkan dengan daging ikan patin sebanyak $10 \%$ lebih tinggi dibandingkan dengan kandungan kecimpring tanpa penambahan daging ikan patin. Kandungan protein kecimpring meningkat cukup tinggi dibandingkan dengan kandungan yang lainnya. Nilai kandungan protein kecimpring akan semakin meningkat dengan pertambahan daging ikan pada kecimpring, hal ini disebabkan ikan patin memiliki kandungan protein yang cukup tinggi. Kandungan protein ikan patin adalah $12,94 \%$ (Suryaningrum $e t$ al. 2010). Kadar protein kecimpring dengan penambahan daging ikan patin $10 \%$ adalah5,81\%. Menurut (SNI 2713.1-2009), kadar protein minimum dalam kerupuk mentah sebesar 5\%. Maka kadar protein kecimpring yang diperoleh dari hasil uji proksimat sudah memenuhi SNI 2713.1-2009, sehingga kecimpring dengan penambahan daging patin
$10 \%$ tersebut dapat dikatakan sebagai kerupuk sumber protein. Kerupuk ikan patin berpotensi untuk dijadikan sebagai makanan ringan yang kaya protein (Hustiany 2005).

\section{Kesimpulan}

Penambahan daging ikan pada kecimpring singkong perlakuan penambahan daging ikan patin 10\% menghasilkan kecimpring yang paling disukai dibandingkan dengan perlakuan lainnya, dengan nilai alternatif tertinggi yaitu 7,20 ; kadar air $11,45 \%$; protein $5,81 \%$; lemak $1,20 \%$ dan abu $4,82 \%$.

\section{Ucapan Terima Kasih}

Ucapan terima kasih disampaikan kepada Kementerian Riset, Teknologi dan Pendidikan tinggi atas dana hibah Penelitian Unggulan Perguruan Tinggi tahun 2015 yang dikeluarkan untuk membantu pelaksanaan penelitian. 


\section{Daftar Pustaka}

Apriliana, F.D. 2005. Pengaruh Penambahan Daging Ikan Terhadap Karakteristik Keripik Ikan . Skripsi. Fakultas Perikanan dan Ilmu Kelautan Universitas Padjadjaran. Bandung.

Fellows, P. 2000. Food Processing Teknology (Principles and Practise) $2{ }^{\text {nd }}$ Edition. CRC Press. Washington, DC.

Gibert O dan Rakshit SK. 2005. Cassava starch snack formulation using functional shell fish by-products: mechanical, sorption and geometric properties. J Sci Food Agric, 85:19381946.

Hustiany, R. 2005. Karakteristik produk olahan kerupuk dan surimi dari daging ikan patin (Pangasius sutchi) hasil budidaya sebagai sumber protein hewani. Media Gizi dan Keluarga 29(2):66-74.

Niamnuy C, Devahastin S, Soponronnarit S, Raghavan GSV. 2008. Kinetics of astaxanthin degradation and color changes of dried shrimp during storage. J Food Eng. 87: 591-600.

Soekarto ST. 1985. Penilaian Organoleptik. Bina Aksara. Jakarta.

Sukmaningrum ,S., L. Sulistyo, P.H.T. Sudibya. 2009. Komposisi tubuh dan Model Lipostatik Ikan bawal air tawar (Colossoma macropomum) yang dipuasakan secara periodik. Fakultas Biologi Universitas Jenderal Sudirman. Purwokerto.

Suryaningrum, TD., Ijah Muljanah, Evi Tahapari. 2010. Profil sensori dan nilai gizi beberapa jenis ikan patin dan hybrid nasutus. Jurnal Pascapanen dan Bioteknologi Kelautan dan Perikanan Vol. 5 No. 2. 153-164.

Suyanto SR. 1994. Nila. Penebar Swadaya. Jakarta.

Winarno FG. 2008. Kimia Pangan dan Gizi. PT. Gramedia Pustaka Utama. Jakarta. 